\title{
Linear Dependence of Balances for Non-Redox Electrolytic Systems
}

\author{
Anna M. Michałowska-Kaczmarczyk¹, Tadeusz Michałowski2* \\ ${ }^{1}$ Department of Oncology, The University Hospital in Cracow, Cracow, Poland \\ ${ }^{2}$ Faculty of Engineering and Chemical Technology, Technical University of Cracow, Cracow, Poland \\ Email: michalot@o2.pl
}

Received 12 October 2014; revised 29 November 2014; accepted 11 December 2014

Copyright (C) 2014 by authors and Scientific Research Publishing Inc.

This work is licensed under the Creative Commons Attribution International License (CC BY).

http://creativecommons.org/licenses/by/4.0/

cc) (i) Open Access

\section{Abstract}

Two complex dynamic non-redox systems are considered as examples, providing interdependent linear equations. A simple and efficient linear combination method that leads the system of equations to the identity, $0=0$, is used for this purpose. These examples are clear confirmations of the general property differentiating non-redox and redox electrolytic systems. This property is involved with linear dependence or independence of $2 \cdot f(\mathbf{O})-f(\mathbf{H})$ on charge and elemental/ core balances for elements/cores $\neq \mathbf{H}, \mathbf{O}$, where $f(\mathbf{H})$ and $f(\mathrm{O})$ are elemental balances for $\mathrm{H}$ and 0 , respectively.

\section{Keywords}

Titration, Liebig-Denigès Method, Complexonometric Detemination of Zinc

\section{Introduction}

In numerous examples of electrolytic redox systems presented in our previous papers [1]-[4], it was found that the linear combination $2 \cdot f(\mathrm{O})-f(\mathrm{H})$ of elemental balances: $f(\mathrm{H})$ for $\mathrm{H}$ and $f(\mathrm{O})$ for $\mathrm{O}$ jest is linearly independent on charge and elemental/core balances for elements/cores different from $\mathrm{H}$ and $\mathrm{O}$. This linear independence proves that $2 \cdot f(\mathrm{O})-f(\mathrm{H})$ is a new equation, considered as the starting form of the electron balance (GEB) related to the redox system in question. In this way it has been shown, inter alia, that the simplest form of GEB related to a redox system in mixed-solvent media is the same, regardless the solvent composition-assuming that the solutes do not form with solvents other species (except those known from aqueous media) besides solvates [5]-[7].

*Corresponding author.

How to cite this paper: Michałowska-Kaczmarczyk, A.M. and Michałowski, T. (2014) Linear Dependence of Balances for Non-Redox Electrolytic Systems. American Journal of Analytical Chemistry, 5, 1285-1289. 
For non-redox systems, it was stated that the linear combination $2 \cdot f(\mathrm{O})-f(\mathrm{H})$ is linearly dependent on charge and elemental/core balances for elements/cores $\neq \mathrm{H}, \mathrm{O}$. This can easily be stated by transformation of the linear combination of the relevant equations to the identity, $0=0$. In this work, this kind of transformation will be applied to two relatively complex systems involved with 1) determination of cyanide according to LiebigDenigès method [8] and 2) complexometric titration of zinc with EDTA [9].

\section{Liebig-Denigès Method of Cyanide Determination}

In the system involved with Liebig-Denigès method, $V \mathrm{~mL}$ of the solution composed of $\mathrm{AgNO}_{3}\left(\mathrm{~N}_{01}\right)+\mathrm{H}_{2} \mathrm{O}\left(\mathrm{N}_{02}\right)$ is added into $V_{0} \mathrm{~mL}$ of the solution composed of $\mathrm{NaCN}\left(\mathrm{N}_{03}\right)+\mathrm{KI}\left(\mathrm{N}_{04}\right)+\mathrm{NH}_{3}\left(\mathrm{~N}_{05}\right)+\mathrm{H}_{2} \mathrm{O}\left(\mathrm{N}_{06}\right) \mathrm{H}_{2} \mathrm{O}\left(\mathrm{N}_{06}\right)$. At defined stage of the process, the following species are present in the system:

$\mathrm{H}_{2} \mathrm{O}\left(\mathrm{N}_{1}\right), \mathrm{H}^{+}\left(\mathrm{N}_{2}\right), \mathrm{OH}^{-}\left(\mathrm{N}_{3}, \mathrm{n}_{3}\right), \mathrm{Na}^{+}\left(\mathrm{N}_{4}, \mathrm{n}_{4}\right), \mathrm{K}^{+}\left(\mathrm{N}_{5}, \mathrm{n}_{5}\right), \mathrm{NO}_{3}^{-}\left(\mathrm{N}_{6}, \mathrm{n}_{6}\right), \mathrm{HCN}\left(\mathrm{N}_{7}, \mathrm{n}_{7}\right), \mathrm{CN}^{-}\left(\mathrm{N}_{8}, \mathrm{n}_{8}\right)$, $\mathrm{NH}_{4}^{+}\left(\mathrm{N}_{9}, \mathrm{n}_{9}\right), \mathrm{NH}_{3}\left(\mathrm{~N}_{11}, \mathrm{n}_{11}\right), \mathrm{Ag}^{+}\left(\mathrm{N}_{12}, \mathrm{n}_{12}\right), \operatorname{AgOH}\left(\mathrm{N}_{13}, \mathrm{n}_{13}\right), \operatorname{Ag}(\mathrm{OH})_{2}^{-}\left(\mathrm{N}_{14}, \mathrm{n}_{14}\right), \operatorname{Ag}(\mathrm{OH})_{3}^{2-}\left(\mathrm{N}_{15}, \mathrm{n}_{15}\right)$, $\operatorname{Ag}(\mathrm{CN})_{2}^{-}\left(\mathrm{N}_{16}, \mathrm{n}_{16}\right), \operatorname{Ag}(\mathrm{CN})_{3}^{2-}\left(\mathrm{N}_{17}, \mathrm{n}_{17}\right), \operatorname{Ag}(\mathrm{CN})_{4}^{3-}\left(\mathrm{N}_{18}, \mathrm{n}_{18}\right), \operatorname{AgI}\left(\mathrm{N}_{19}, \mathrm{n}_{19}\right), \operatorname{AgI}_{2}^{-}\left(\mathrm{N}_{21}, \mathrm{n}_{21}\right), \operatorname{AgI}_{3}^{2-}\left(\mathrm{N}_{22}\right.$, $\left.\mathrm{n}_{22}\right), \operatorname{AgI}_{4}^{3-}\left(\mathrm{N}_{23}, \mathrm{n}_{23}\right), \operatorname{AgNH}_{3}^{+}\left(\mathrm{N}_{24}, \mathrm{n}_{24}\right), \operatorname{Ag}\left(\mathrm{NH}_{3}\right)_{2}^{4}\left(\mathrm{~N}_{25}, \mathrm{n}_{25}\right), \operatorname{AgI}_{(s)}\left(\mathrm{N}_{26}, \mathrm{n}_{26}\right), \mathrm{I}^{-}\left(\mathrm{N}_{27}, \mathrm{n}_{27}\right)$.

From the balances:

- $f(\mathrm{H})$

$$
\begin{aligned}
2 \mathrm{~N}_{1} & +\mathrm{N}_{2}\left(1+2 \mathrm{n}_{2}\right)+\mathrm{N}_{3}\left(1+2 \mathrm{n}_{3}\right)+2 \mathrm{~N}_{4} \mathrm{n}_{4}+2 \mathrm{~N}_{5} \mathrm{n}_{5}+2 \mathrm{~N}_{6} \mathrm{n}_{6}+\mathrm{N}_{7}\left(1+2 \mathrm{n}_{7}\right)+2 \mathrm{~N}_{8} \mathrm{n}_{8}+\mathrm{N}_{9}\left(4+2 \mathrm{n}_{9}\right) \\
& +\mathrm{N}_{11}\left(3+2 \mathrm{n}_{11}\right)+2 \mathrm{~N}_{12} \mathrm{n}_{12}+\mathrm{N}_{13}\left(1+2 \mathrm{n}_{13}\right)+\mathrm{N}_{14}\left(2+2 \mathrm{n}_{14}\right)+\mathrm{N}_{15}\left(3+2 \mathrm{n}_{15}\right)+2 \mathrm{~N}_{16} \mathrm{n}_{16}+2 \mathrm{~N}_{17} \mathrm{n}_{17} \\
& +2 \mathrm{~N}_{18} \mathrm{n}_{18}+2 \mathrm{~N}_{19} \mathrm{n}_{19}+2 \mathrm{~N}_{21} \mathrm{n}_{21}+2 \mathrm{~N}_{22} \mathrm{n}_{22}+2 \mathrm{~N}_{23} \mathrm{n}_{23}+\mathrm{N}_{24}\left(3+2 \mathrm{n}_{24}\right)+\mathrm{N}_{25}\left(6+2 \mathrm{n}_{25}\right)+2 \mathrm{~N}_{26} \mathrm{n}_{26}+2 \mathrm{~N}_{27} \mathrm{n}_{27} \\
= & 2 \mathrm{~N}_{02}+3 \mathrm{~N}_{05}+2 \mathrm{~N}_{06},
\end{aligned}
$$

- $f(\mathrm{O})$

$$
\begin{aligned}
N_{1} & +N_{2} n_{2}+N_{3}\left(1+n_{3}\right)+N_{4} n_{4}+N_{5} n_{5}+N_{6}\left(3+n_{6}\right)+N_{7} n_{7}+N_{8} n_{8}+N_{9} n_{9}+N_{11} n_{11} \\
& +N_{12} n_{12}+N_{13}\left(1+n_{13}\right)+N_{14}\left(2+n_{14}\right)+N_{15}\left(3+n_{15}\right)+N_{16} n_{16}+N_{17} n_{17}+N_{18} n_{18}+N_{19} n_{19} \\
& +N_{21} n_{21}+N_{22} n_{22}+N_{23} n_{23}+N_{24} n_{24}+N_{25} n_{25}+N_{26} n_{26}+N_{27} n_{27}=3 N_{01}+N_{02}+N_{06}
\end{aligned}
$$

we have

- $2 \cdot f(\mathrm{O})-f(\mathrm{H})$

$$
-\mathrm{N}_{2}+\mathrm{N}_{3}+6 \mathrm{~N}_{6}-\mathrm{N}_{7}-4 \mathrm{~N}_{9}-3 \mathrm{~N}_{11}+\mathrm{N}_{13}+2 \mathrm{~N}_{14}+3 \mathrm{~N}_{15}-3 \mathrm{~N}_{24}-6 \mathrm{~N}_{25}=6 \mathrm{~N}_{01}-3 \mathrm{~N}_{05}
$$

Addition of (3) to charge balance (4) and balances: $f(\mathrm{Na})(5), f(\mathrm{~K})(6), 5 f\left(\mathrm{NO}_{3}\right)(7), f(\mathrm{CN})(8), 3 f\left(\mathrm{NH}_{3}\right)(9)$, $f(\mathrm{Ag})(10)$ and $f(\mathrm{I})(11)$

$$
\begin{aligned}
& \mathrm{N}_{2}-\mathrm{N}_{3}+\mathrm{N}_{4}+\mathrm{N}_{5}-\mathrm{N}_{6}-\mathrm{N}_{8}+\mathrm{N}_{9}+\mathrm{N}_{12}-\mathrm{N}_{14}-2 \mathrm{~N}_{15}-\mathrm{N}_{16}-2 \mathrm{~N}_{17}-3 \mathrm{~N}_{18}-\mathrm{N}_{21}-2 \mathrm{~N}_{22}-3 \mathrm{~N}_{23} \\
& +\mathrm{N}_{24}+\mathrm{N}_{25}-\mathrm{N}_{27}=0 \text {, } \\
& \mathrm{N}_{03}=\mathrm{N}_{4} \\
& \mathrm{~N}_{04}=\mathrm{N}_{5} \\
& 5 \mathrm{~N}_{01}=5 \mathrm{~N}_{6} \\
& \mathrm{~N}_{7}+\mathrm{N}_{8}+2 \mathrm{~N}_{16}+3 \mathrm{~N}_{17}+4 \mathrm{~N}_{18}=\mathrm{N}_{03} \\
& 3 \mathrm{~N}_{9}+3 \mathrm{~N}_{11}+3 \mathrm{~N}_{24}+6 \mathrm{~N}_{25}=3 \mathrm{~N}_{05} \\
& \mathrm{~N}_{01}=\mathrm{N}_{12}+\mathrm{N}_{13}+\mathrm{N}_{14}+\mathrm{N}_{15}+\mathrm{N}_{16}+\mathrm{N}_{17}+\mathrm{N}_{18}+\mathrm{N}_{19}+\mathrm{N}_{21}+\mathrm{N}_{22}+\mathrm{N}_{23}+\mathrm{N}_{24}+\mathrm{N}_{25}+\mathrm{N}_{26} \\
& \mathrm{~N}_{19}+2 \mathrm{~N}_{21}+3 \mathrm{~N}_{22}+4 \mathrm{~N}_{23}+\mathrm{N}_{26}+\mathrm{N}_{27}=\mathrm{N}_{04}
\end{aligned}
$$

gives the identity, $0=0$, i.e., (3) is not an independent balance in the system. The identity is also valid before crossing the solubility product for AgI(s).

\section{Complexometric Titration of Zinc with EDTA}

Let us consider $V_{0} \mathrm{~mL}$ of titrand (D), containing $\mathrm{ZnSO}_{4}\left(\mathrm{C}_{0}\right)+\mathrm{NH}_{3}\left(\mathrm{C}_{1}\right)+\mathrm{NH}_{4} \mathrm{Cl}\left(\mathrm{C}_{2}\right)+\mathrm{NaH}_{2} \mathrm{In}$ (erio T, 
$\mathrm{C}_{\text {OIn }}$ ) titrated with $V \mathrm{~mL}$ of titrant (T) containing EDTA (C).

The titrand is composed of $\mathrm{N}_{01}$ molecules of $\mathrm{ZnSO}_{4} \cdot 7 \mathrm{H}_{2} \mathrm{O}$ (goslarite), $\mathrm{N}_{02}$ molecules of $\mathrm{NH}_{3}, \mathrm{~N}_{03}$ molecules of $\mathrm{NH}_{4} \mathrm{Cl}, \mathrm{N}_{04}$ molecules of $\mathrm{NaH}_{2} \mathrm{In}=\mathrm{C}_{20} \mathrm{H}_{12} \mathrm{~N}_{3} \mathrm{O}_{7} \mathrm{SNa}, \mathrm{N}_{05}$ molecules of $\mathrm{H}_{2} \mathrm{O}$ and the titrant is composed of $\mathrm{N}_{06}$ molecules of EDTA $=\mathrm{Na}_{2} \mathrm{H}_{2} \mathrm{~L} \cdot 2 \mathrm{H}_{2} \mathrm{O}=\mathrm{C}_{10} \mathrm{H}_{14} \mathrm{~N}_{2} \mathrm{O}_{8} \mathrm{Na}_{2} \cdot 2 \mathrm{H}_{2} \mathrm{O}$ and $\mathrm{N}_{07}$ molecules of $\mathrm{H}_{2} \mathrm{O}$, at defined point of titration ( $\mathrm{V} \mathrm{mL}$ of $\mathrm{T}$ added). In the system in question, the following species are formed:

$\mathrm{H}_{2} \mathrm{O}\left(\mathrm{N}_{1}\right), \mathrm{H}^{+}\left(\mathrm{N}_{2}, \mathrm{n}_{2}\right), \mathrm{OH}^{-}\left(\mathrm{N}_{3}, \mathrm{n}_{3}\right), \mathrm{HSO}_{4}^{-}\left(\mathrm{N}_{4}, \mathrm{n}_{4}\right), \mathrm{SO}_{4}^{2-}\left(\mathrm{N}_{5}, \mathrm{n}_{5}\right), \mathrm{Cl}^{-}\left(\mathrm{N}_{6}, \mathrm{n}_{6}\right), \mathrm{Na}^{+}\left(\mathrm{N}_{7}, \mathrm{n}_{7}\right), \mathrm{NH}_{4}^{+}\left(\mathrm{N}_{8}, \mathrm{n}_{8}\right)$, $\mathrm{NH}_{3}\left(\mathrm{~N}_{9}, \mathrm{n}_{9}\right), \mathrm{Zn}^{2+}\left(\mathrm{N}_{11}, \mathrm{n}_{11}\right), \mathrm{ZnOH}^{+}\left(\mathrm{N}_{12}, \mathrm{n}_{12}\right)$, soluble complex $\mathrm{Zn}(\mathrm{OH})_{2}\left(\mathrm{~N}_{13}, \mathrm{n}_{13}\right), \mathrm{Zn}(\mathrm{OH})_{3}^{-}\left(\mathrm{N}_{14}, \mathrm{n}_{14}\right)$, $\mathrm{Zn}(\mathrm{OH})_{4}^{2-}\left(\mathrm{H}_{2} \mathrm{~L}^{2-}\right)\left(\mathrm{N}_{15}, \mathrm{n}_{15}\right), \mathrm{ZnNH}_{3}^{2+}\left(\mathrm{N}_{16}, \mathrm{n}_{16}\right), \mathrm{Zn}\left(\mathrm{NH}_{3}\right)_{2}^{2+}\left(\mathrm{N}_{17}, \mathrm{n}_{17}\right), \mathrm{Zn}\left(\mathrm{NH}_{3}\right)^{2+}\left(\mathrm{N}_{18}, \mathrm{n}_{18}\right), \mathrm{Zn}\left(\mathrm{NH}_{3}\right)_{4-}^{2+}$ $\left(\mathrm{N}_{19}, \mathrm{n}_{19}\right), \mathrm{ZnCl}^{+}\left(\mathrm{N}_{21}, \mathrm{n}_{21}\right) ; \mathrm{ZnSO}_{4}\left(\mathrm{~N}_{22}, \mathrm{n}_{22}\right), \mathrm{C}_{20} \mathrm{H}_{13} \mathrm{~N}_{3} \mathrm{O}_{7} \mathrm{~S}\left(\mathrm{~N}_{23}, \mathrm{n}_{23}\right), \mathrm{C}_{20} \mathrm{H}_{12} \mathrm{~N}_{3} \mathrm{O}_{7} \mathrm{~S}^{-}\left(\mathrm{N}_{24}, \mathrm{n}_{24}\right), \mathrm{C}_{20} \mathrm{H}_{11} \mathrm{~N}_{3} \mathrm{O}_{7} \mathrm{~S}^{2-}$ $\left(\mathrm{N}_{25}, \mathrm{n}_{25}\right), \mathrm{C}_{20} \mathrm{H}_{10} \mathrm{~N}_{3} \mathrm{O}_{7} \mathrm{~S}^{3-}\left(\mathrm{N}_{26}, \mathrm{n}_{26}\right), \mathrm{C}_{20} \mathrm{H}_{10} \mathrm{~N}_{3} \mathrm{O}_{7} \mathrm{SZn}^{-}\left(\mathrm{N}_{27}, \mathrm{n}_{27}\right),\left(\mathrm{C}_{20} \mathrm{H}_{10} \mathrm{~N}_{3} \mathrm{O}_{7} \mathrm{~S}\right) \mathrm{Zn}^{4-}\left(\mathrm{N}_{28}, \mathrm{n}_{28}\right), \mathrm{C}_{10} \mathrm{H}_{18} \mathrm{~N}_{2} \mathrm{O}_{8}^{2+}$ $\left(\mathrm{H}_{6} \mathrm{~L}^{2+}\right)\left(\mathrm{N}_{29}, \mathrm{n}_{29}\right), \mathrm{C}_{10} \mathrm{H}_{17} \mathrm{~N}_{2} \mathrm{O}_{8}^{+}\left(\mathrm{H}_{5} \mathrm{~L}^{+}\right)\left(\mathrm{N}_{31}, \mathrm{n}_{31}\right), \mathrm{C}_{10} \mathrm{H}_{16} \mathrm{~N}_{2} \mathrm{O}_{8}\left(\mathrm{H}_{4} \mathrm{~L}\right)\left(\mathrm{N}_{32}, \mathrm{n}_{32}\right), \mathrm{C}_{10} \mathrm{H}_{15} \mathrm{~N}_{2} \mathrm{O}_{8}^{-}\left(\mathrm{H}_{3} \mathrm{~L}^{-1}\right)\left(\mathrm{N}_{33}\right.$, $\left.\mathrm{n}_{33}\right), \mathrm{C}_{10} \mathrm{H}_{14} \mathrm{~N}_{2} \mathrm{O}_{8}^{2-}\left(\mathrm{H}_{2} \mathrm{~L}^{2-}\right)\left(\mathrm{N}_{34}, \mathrm{n}_{34}\right), \mathrm{C}_{10} \mathrm{H}_{13} \mathrm{~N}_{2} \mathrm{O}_{8}^{3-}\left(\mathrm{HL}^{3-}\right)\left(\mathrm{N}_{35}, \mathrm{n}_{35}\right), \mathrm{C}_{10} \mathrm{H}_{12} \mathrm{~N}_{2} \mathrm{O}_{8}^{4-}\left(\mathrm{L}^{4-}\right)\left(\mathrm{N}_{36}, \mathrm{n}_{36}\right)$, $\mathrm{C}_{10} \mathrm{H}_{13} \mathrm{~N}_{2} \mathrm{O}_{8} \mathrm{Zn}^{-}\left(\mathrm{ZnHL}^{-}\right)\left(\mathrm{N}_{37}, \mathrm{n}_{37}\right), \mathrm{C}_{10} \mathrm{H}_{12} \mathrm{~N}_{2} \mathrm{O}_{8} \mathrm{Zn}^{2-}\left(\mathrm{ZnL}^{2-}\right)\left(\mathrm{N}_{38}, \mathrm{n}_{38}\right), \mathrm{C}_{10} \mathrm{H}_{13} \mathrm{~N}_{2} \mathrm{O}_{9} \mathrm{Zn}^{3-}\left(\mathrm{ZnOHL}^{3-}\right)$ $\left(\mathrm{N}_{39}, \mathrm{n}_{39}\right)$.

The complex $\mathrm{ZnOHL}^{3-}$ is formed in reaction between $\mathrm{ZnOH}^{+}$and $\mathrm{L}^{4-}$. The species can be arranged in the following balances:

- $f(\mathrm{H})$

$$
\begin{aligned}
2 N_{1} & +N_{2}\left(1+2 n_{2}\right)+N_{3}\left(1+2 n_{3}\right)+N_{4}\left(1+2 n_{4}\right)+2 N_{5} n_{5}+2 N_{6} n_{6}+2 N_{7} n_{7}+N_{8}\left(4+2 n_{8}\right)+N_{9}\left(3+2 n_{9}\right) \\
& +2 N_{11} n_{11}+N_{12}\left(1+2 n_{12}\right)+N_{13}\left(2+2 n_{13}\right)+N_{14}\left(3+2 n_{14}\right)+N_{15}\left(4+2 n_{15}\right)+N_{16}\left(3+2 n_{16}\right) \\
& +N_{17}\left(6+2 n_{17}\right)+N_{18}\left(9+2 n_{18}\right)+N_{19}\left(12+2 n_{19}\right)+2 N_{21} n_{21}+2 N_{22} n_{22}+N_{23}\left(13+2 n_{23}\right) \\
& +N_{24}\left(12+2 n_{24}\right)+N_{25}\left(11+2 n_{25}\right)+N_{26}\left(10+2 n_{26}\right)+N_{27}\left(10+2 n_{27}\right)+N_{28}\left(20+2 n_{28}\right)+N_{29}\left(18+2 n_{29}\right) \\
& +N_{31}\left(17+2 n_{31}\right)+N_{32}\left(16+2 n_{32}\right)+N_{33}\left(15+2 n_{33}\right)+N_{34}\left(14+2 n_{34}\right)+N_{35}\left(13+2 n_{35}\right)+N_{36}\left(12+2 n_{36}\right) \\
& +N_{37}\left(13+2 n_{37}\right)+N_{38}\left(12+2 n_{38}\right)+N_{39}\left(13+2 n_{39}\right) \\
= & 14 N_{01}+3 N_{02}+4 N_{03}+12 N_{04}+2 N_{05}+18 N_{06}+2 N_{07},
\end{aligned}
$$

- $f(\mathrm{O})$

$$
\begin{aligned}
N_{1} & +N_{2} n_{2}+N_{3}\left(1+n_{3}\right)+N_{4}\left(4+n_{4}\right)+N_{5}\left(4+n_{5}\right)+N_{6} n_{6}+N_{7} n_{7}+N_{8} n_{8}+N_{9} n_{9}+N_{11} n_{11} \\
& +N_{12}\left(1+n_{12}\right)+N_{13}\left(2+n_{13}\right)+N_{14}\left(3+n_{14}\right)+N_{15}\left(4+n_{15}\right)+N_{16} n_{16}+N_{17} n_{17}+N_{18} n_{18} \\
& +N_{19} n_{19}+N_{21} n_{21}+N_{22}\left(4+n_{22}\right)+N_{23}\left(7+n_{23}\right)+N_{24}\left(7+n_{24}\right)+N_{25}\left(7+n_{25}\right)+N_{26}\left(7+n_{26}\right) \\
& +N_{27}\left(7+n_{27}\right)+N_{28}\left(14+n_{28}\right)+N_{29}\left(8+n_{29}\right)+N_{31}\left(8+n_{31}\right)+N_{32}\left(8+n_{32}\right)+N_{33}\left(8+n_{33}\right) \\
& +N_{34}\left(8+n_{34}\right)+N_{35}\left(8+n_{35}\right)+N_{36}\left(8+n_{36}\right)+N_{37}\left(8+n_{37}\right)+N_{38}\left(8+n_{38}\right)+N_{39}\left(9+n_{39}\right) \\
= & 11 N_{01}+7 N_{04}+N_{05}+10 N_{06}+N_{07},
\end{aligned}
$$

The balance $2 \cdot f(\mathrm{O})-f(\mathrm{H})$, obtained from Equations (12) and (13), is as follows

$$
\begin{aligned}
-\mathrm{N}_{2} & +\mathrm{N}_{3}+7 \mathrm{~N}_{4}+8 \mathrm{~N}_{5}-4 \mathrm{~N}_{8}-3 \mathrm{~N}_{9}+\mathrm{N}_{12}+2 \mathrm{~N}_{13}+3 \mathrm{~N}_{14}+4 \mathrm{~N}_{15}-3 \mathrm{~N}_{16}-6 \mathrm{~N}_{17} \\
& -9 \mathrm{~N}_{18}-12 \mathrm{~N}_{19}+8 \mathrm{~N}_{22}+\mathrm{N}_{23}+2 \mathrm{~N}_{24}+3 \mathrm{~N}_{25}+4 \mathrm{~N}_{26}+4 \mathrm{~N}_{27}+8 \mathrm{~N}_{28}-2 \mathrm{~N}_{29}-\mathrm{N}_{31} \\
& +\mathrm{N}_{33}+2 \mathrm{~N}_{34}+3 \mathrm{~N}_{35}+4 \mathrm{~N}_{36}+3 \mathrm{~N}_{37}+4 \mathrm{~N}_{38}+5 \mathrm{~N}_{39}=8 \mathrm{~N}_{01}-3 \mathrm{~N}_{02}-4 \mathrm{~N}_{03}+2 \mathrm{~N}_{04}+2 \mathrm{~N}_{06},
\end{aligned}
$$

Addition of (14) to charge balance (15) and balances for $2 \cdot f(\mathrm{Zn})(16), f(\mathrm{Cl})(17), f(\mathrm{Na})$ (18), 6. $f\left(\mathrm{SO}_{4}\right)$ (19), 3. $f\left(\mathrm{NH}_{3}\right)$ (20), $f\left(\mathrm{C}_{20} \mathrm{H}_{10} \mathrm{~N}_{3} \mathrm{O}_{7} \mathrm{~S}\right)$ (21), and $0 \cdot f\left(\mathrm{C}_{10} \mathrm{H}_{12} \mathrm{~N}_{2} \mathrm{O}_{8}\right)$ (22):

$$
\begin{gathered}
\mathrm{N}_{2}-\mathrm{N}_{3}-\mathrm{N}_{4}-2 \mathrm{~N}_{5}-\mathrm{N}_{6}+\mathrm{N}_{7}+\mathrm{N}_{8}+2 \mathrm{~N}_{11}+\mathrm{N}_{12}-\mathrm{N}_{14}-2 \mathrm{~N}_{15}+2 \mathrm{~N}_{16}+2 \mathrm{~N}_{17}+2 \mathrm{~N}_{18}+2 \mathrm{~N}_{19}+\mathrm{N}_{21}-\mathrm{N}_{24} \\
-2 \mathrm{~N}_{25}-3 \mathrm{~N}_{26}-\mathrm{N}_{27}-4 \mathrm{~N}_{28}+2 \mathrm{~N}_{29}+\mathrm{N}_{31}-\mathrm{N}_{33}-2 \mathrm{~N}_{34}-3 \mathrm{~N}_{35}-4 \mathrm{~N}_{36}-\mathrm{N}_{37}-2 \mathrm{~N}_{38}-3 \mathrm{~N}_{39}=0, \\
2 \mathrm{~N}_{01}=2 \mathrm{~N}_{11}+2 \mathrm{~N}_{12}+2 \mathrm{~N}_{13}+2 \mathrm{~N}_{14}+2 \mathrm{~N}_{15}+2 \mathrm{~N}_{16}+2 \mathrm{~N}_{17}+2 \mathrm{~N}_{18}+2 \mathrm{~N}_{19}+2 \mathrm{~N}_{21}+2 \mathrm{~N}_{22}+2 \mathrm{~N}_{27}+2 \mathrm{~N}_{28} \\
+2 \mathrm{~N}_{37}+2 \mathrm{~N}_{38}+2 \mathrm{~N}_{39}, \quad \\
\mathrm{~N}_{6}+\mathrm{N}_{21}=\mathrm{N}_{03}
\end{gathered}
$$




$$
\begin{gathered}
\mathrm{N}_{04}+2 \mathrm{~N}_{06}=\mathrm{N}_{7} \\
6 \mathrm{~N}_{01}=6 \mathrm{~N}_{4}+6 \mathrm{~N}_{5}+6 \mathrm{~N}_{22} \\
3 \mathrm{~N}_{8}+3 \mathrm{~N}_{9}+3 \mathrm{~N}_{16}+6 \mathrm{~N}_{17}+9 \mathrm{~N}_{18}+12 \mathrm{~N}_{19}=3 \mathrm{~N}_{02}+3 \mathrm{~N}_{03} \\
\mathrm{~N}_{04}=\mathrm{N}_{23}+\mathrm{N}_{24}+\mathrm{N}_{25}+\mathrm{N}_{26}+\mathrm{N}_{27}+2 \mathrm{~N}_{28} \\
0 \cdot \mathrm{N}_{29}+0 \cdot \mathrm{N}_{31}+0 \cdot \mathrm{N}_{32}+0 \cdot \mathrm{N}_{33}+0 \cdot \mathrm{N}_{34}+0 \cdot \mathrm{N}_{35}+0 \cdot \mathrm{N}_{36}+0 \cdot \mathrm{N}_{37}+0 \cdot \mathrm{N}_{38}+0 \cdot \mathrm{N}_{39}=0 \cdot \mathrm{N}_{06}
\end{gathered}
$$

gives the identity, $0=0$, that testifies about linear dependence between the balances, i.e., Equation (14) is linearly dependent on other balances in the system. Note that the Equations (19)-(22) are specified separately, according to different "cores": $\mathrm{SO}_{4}, \mathrm{NH}_{3}, \mathrm{C}_{20} \mathrm{H}_{10} \mathrm{~N}_{3} \mathrm{O}_{7} \mathrm{~S}, \mathrm{C}_{10} \mathrm{H}_{12} \mathrm{~N}_{2} \mathrm{O}_{8}$. Note that $\mathrm{N}$ enters the compounds and species in Equations (20)-(22); S enters the compounds and species in Equations (19) and (21); C enters the compounds and species in Equations (21) and (22). However, none transformations occur between the "cores" of the species that belong to different concentration balances. Generalizing, for any non-redox system, there are some numbers/multipliers for the relevant equations that reduce the sum received to the identity.

Referring again to Equation (21), related to the species involved with erio $\mathrm{T}$, one can write the elemental balances:

$$
\begin{gathered}
20 N_{23}+20 N_{24}+20 N_{25}+20 N_{26}+20 N_{27}+40 N_{28}=20 N_{04} \text { (for C), } \\
3 N_{23}+3 N_{24}+3 N_{25}+3 N_{26}+3 N_{27}+6 N_{28}=3 N_{04}(\text { for } N), N_{23}+N_{24}+N_{25}+N_{26}+N_{27}+2 N_{28}=N_{04} \text { (for } S \text { ), }
\end{gathered}
$$

and

$$
7 \mathrm{~N}_{23}+7 \mathrm{~N}_{24}+7 \mathrm{~N}_{25}+7 \mathrm{~N}_{26}+7 \mathrm{~N}_{27}+14 \mathrm{~N}_{28}=7 \mathrm{~N}_{04} \text { (for O). }
$$

All the equations are identical and equivalent to Equation (21), because the "core" $\mathrm{C}_{20} \mathrm{H}_{10} \mathrm{~N}_{3} \mathrm{O}_{7} \mathrm{~S}$ is unchanged in reactions occurred during the titration. Similarly, the species involved with EDTA, see Equation (22), fulfill the relations:

$$
10 N_{29}+10 N_{31}+10 N_{32}+10 N_{33}+10 N_{34}+10 N_{35}+10 N_{36}+10 N_{37}+10 N_{38}+10 N_{39}=10 N_{06} \text { (for C), }
$$

and

$$
3 \mathrm{~N}_{29}+3 \mathrm{~N}_{31}+3 \mathrm{~N}_{32}+3 \mathrm{~N}_{33}+3 \mathrm{~N}_{34}+3 \mathrm{~N}_{35}+3 \mathrm{~N}_{36}+3 \mathrm{~N}_{37}+3 \mathrm{~N}_{38}+3 \mathrm{~N}_{39}=3 \mathrm{~N}_{06} \text { (for } \mathrm{N} \text { ). }
$$

Both equations are equivalent to $f\left(\mathrm{C}_{10} \mathrm{H}_{12} \mathrm{~N}_{2} \mathrm{O}_{8}\right)$.

\section{Final Comments}

Checking of linear dependence or independence of algebraic equations [10] is not a mathematical problem of the highest order. However, it requires an additional knowledge of the user, concerning the properties of the matrix $\boldsymbol{A}=\left[a_{i j}\right](i=1, \cdots, m ; j=1, \cdots, n ; n>m)$ of coefficients $a_{i j}$ in the matrix equation $\boldsymbol{A} \boldsymbol{x}=\boldsymbol{b}$, where

$$
\boldsymbol{A}=\left[\begin{array}{ccc}
a_{11} & \cdots & a_{1 n} \\
\cdots & \ddots & \cdots \\
a_{m 1} & \cdots & a_{m n}
\end{array}\right], \quad \boldsymbol{x}=\left[\begin{array}{c}
x_{1} \\
\ldots \\
x_{n}
\end{array}\right], \quad \boldsymbol{b}=\left[\begin{array}{c}
b_{1} \\
\cdots \\
b_{m}
\end{array}\right]
$$

with vectors of variables, $\boldsymbol{x}$, and vector of constant terms, $\boldsymbol{b}$. For explaining these properties, some abstract terms such as (dimension of) vector space, (matrix, kolumn, row) ranks, are used.

It should be noted, however, that the coefficients $a_{i j}$ and $b_{i}$ used in purely algebraic equations

$$
\begin{gathered}
a_{11} x_{1}+\cdots+a_{1 n} x_{n}=b_{1} \\
\cdots \\
a_{m 1} x_{1}+\cdots+a_{m n} x_{n}=b_{m}
\end{gathered}
$$

do not have specific physical or chemical connotations. Assuming the charge balance as the second of the balances (24) considered for this purpose, we state that the coefficients $a_{2 j}$ in this balance are involved with external charges of the species in the system in question and $b_{2}=0$ in the vector $\boldsymbol{b}$. The coefficients $a_{i j}$ in the elemental/core balances are involved with the number of elements/cores in the related species. The coefficients 
in $2 \cdot f(\mathrm{O})-f(\mathrm{H})$ depend on the form of equations for $f(\mathrm{H})$ and $f(\mathrm{O})$.

In this paper, the linear relationship between the balance $2 \cdot f(\mathrm{O})-f(\mathrm{H})$ and charge + elemental/core balances for elements/cores $\neq \mathrm{H}$, O was checked in extremely simple way (indicated in [4]) and proved on examples of two electrolytic non-redox systems, of analytical importance, known from titrimetric analyses. Full complexity of these systems, known from preliminary physicochemical data, is involved in the related balances, expressed in terms of numbers of entities of particular components and species $X_{i}^{z_{i}}$. The related balances can also be expressed in terms of molar concentrations: $\left[X_{i}^{z_{i}}\right]\left(V_{0}+V\right)=10^{3} \times \mathrm{N}_{\mathrm{i}} / \mathrm{N}_{\mathrm{A}}$ for the species $X_{i}^{z_{i}}\left(\mathrm{~N}_{\mathrm{A}}-\right.$ Avogadro's number) and analogous relationships for components forming the titrand $(\mathrm{D})$ and titrant $(\mathrm{T})$ in the related $\mathrm{D}+\mathrm{T}$ system. It should be recalled and emphasized that a linear relationship between $2 \cdot f(\mathrm{O})-f(\mathrm{H})$ and charge + elemental/core balances for elements/cores $\neq \mathrm{H}$, O does not occur for redox systems, and the resulting balance is the basis of formulation of GEB for these systems, obtained according to Approach II to GEB [1]-[7] [11].

\section{References}

[1] Michałowski, T. (2010) The Generalized Approach to Electrolytic Systems: I. Physicochemical and Analytical Implications. Critical Reviews in Analytical Chemistry, 40, 2-16. http://dx.doi.org/10.1080/10408340903001292

[2] Michałowski, T., Toporek, M., Michałowska-Kaczmarczyk, A.M. and Asuero, A.G. (2013) New Trends in Studies on Electrolytic Redox Systems. Electrochimica Acta, 109, 519-531.

http://www.sciencedirect.com/science/article/pii/S0013468613013947 http://dx.doi.org/10.1016/j.electacta.2013.07.125

[3] Michałowski, T., Michałowska-Kaczmarczyk, A.M. and Toporek, M. (2013) Formulation of General Criterion Distinguishing between Non-Redox and Redox Systems. Electrochimica Acta, 112, 199-211

http://www.sciencedirect.com/science/article/pii/S0013468613016836

http://dx.doi.org/10.1016/j.electacta.2013.08.153

[4] Michałowska-Kaczmarczyk, A.M. and Michałowski, T. (2013) Comparative Balancing of Non-Redox and Redox Electrolytic Systems and Its Consequences. American Journal of Analytical Chemistry, 4, 46-53. http://www.scirp.org/journal/PaperInformation.aspx?paperID=38569\#.VGObL2dvHFw http://dx.doi.org/10.4236/ajac.2013.410A1006

[5] Michałowski, T., Pilarski, B., Asuero, A.G. and Michałowska-Kaczmarczyk, A.M. (2014) Chapter 9.4: Modeling of AcidBase Properties in Binary-Solvent Systems. In: Wypych, G., Ed., Handbook of Solvents, Volume 1, Properties, 2nd Edition, ChemTec Publishing, Toronto, 623-648. http://store.elsevier.com/Handbook-of-Solvents-Volume-1/isbn-9781895198645/

[6] Michałowska-Kaczmarczyk, A.M. and Michałowski, T. (2014) Compact Formulation of Redox Systems According to GATES/GEB Principles. Journal of Analytical Sciences, Methods and Instrumentation, 4, 39-45. http://www.scirp.org/journal/PaperInformation.aspx?PaperID=46335\#.VGm1Tmfpt74

[7] Michałowska-Kaczmarczyk, A.M. and Michałowski, T. (2014) Generalized Electron Balance for Dynamic Redox Systems in Mixed-Solvent Media. Journal of Analytical Sciences, Methods and Instrumentation, 4, 102-109. http://www.scirp.org/Journal/PaperInformation.aspx?PaperID=52018\#.VIfpeMkdqUR

[8] Michałowski, T., Asuero, A.G., Ponikvar-Svet, M., Toporek, M., Pietrzyk, A. and Rymanowski, M. (2012) Principles of Computer Programming Applied to Simulated pH-Static Titration of Cyanide According to a MODIFIED LiebigDenigès Method. Journal of Solution Chemistry, 41, 1224-1239. http://dx.doi.org/10.1007/s10953-012-9864-x

[9] Michałowski, T. (2001) Calculations in Analytical Chemistry with Elements of Computer Programming (in Polish), PK, Cracow. http://suw.biblos.pk.edu.pl/resourceDetails\&rId=3974

[10] http://en.wikipedia.org/wiki/System_of_linear_equations

[11] Michałowski, T. (2011) Application of GATES and MATLAB for Resolution of Equilibrium, Metastable and NonEquilibrium Electrolytic Systems, In: Michałowski, T., Ed., Applications of MATLAB in Science and Engineering, InTech-Open Access Publisher in the Fields of Science, Technology and Medicine, Rijeka, Chapter 1, 1-34. http://www.intechopen.com/books/show/title/applications-of-matlab-in-science-and-engineering 
Scientific Research Publishing (SCIRP) is one of the largest Open Access journal publishers. It is currently publishing more than 200 open access, online, peer-reviewed journals covering a wide range of academic disciplines. SCIRP serves the worldwide academic communities and contributes to the progress and application of science with its publication.

Other selected journals from SCIRP are listed as below. Submit your manuscript to us via either submit@scirp.org or Online Submission Portal.
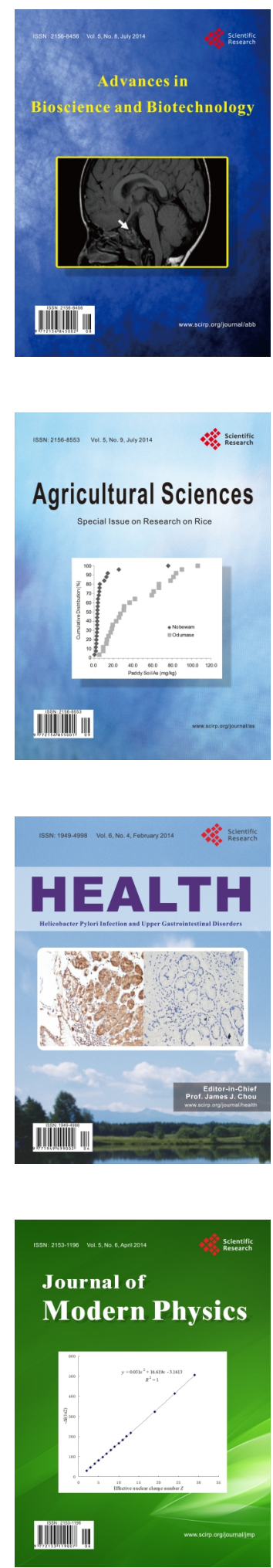
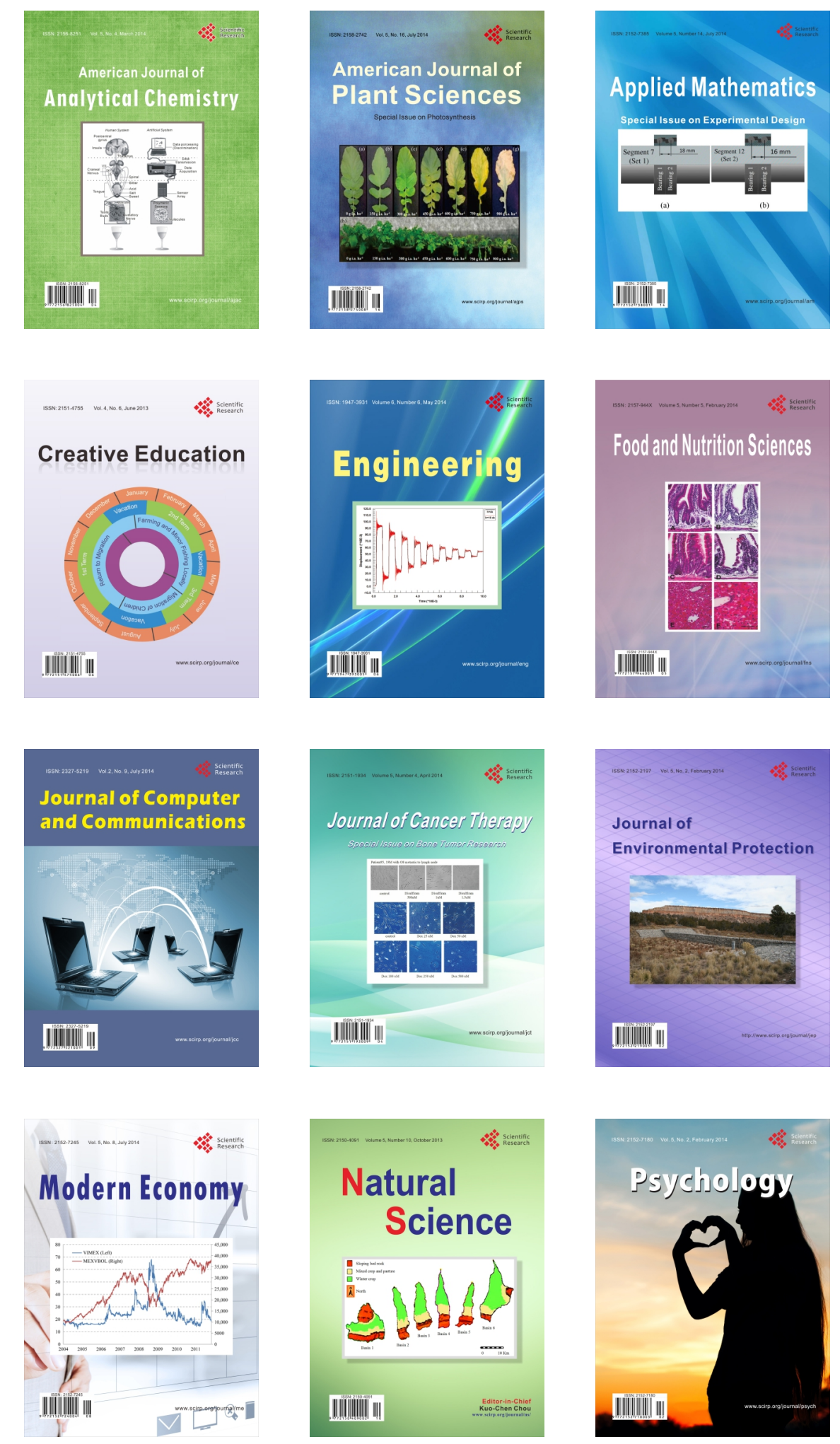